\title{
Breakages and Reconstructions - A Study on The Book of Job from the View of Peripheral Situation Theory
}

\section{Liu Zhuo}

\author{
Xi'an Fanyi University, Xi'an, 710105
}

\begin{abstract}
Key words: Peripheral Situation; breakages; reconstructions; the Book of Job
\end{abstract}
\begin{abstract}
Peripheral Situation was firstly put forward by German existentialist philosopher Karl Theodor Jaspers (1883-1969) . It refers to the situation that "If someone encounters accidents, there will be breakages in their connections with other people, their own ego and even with God. They are likely to doubt themselves, life, experiences and their belief. Eventually, collapses of their individual worlds will ensue." And Peripheral Situation is a common theory of existentialism. With the theory in the study of the Book of Job of the Old Testament, the breakages and reconstruction of Job's ties with God and with other people were analyzed, the reasons behind them and their modern presentation were further explored, and the purpose of this study, namely "peripheral situation is inevitable in one's pursuits of God, truth and his or her ego, without trying, you will never understand the essence and meaning of life", was demonstrated.

Peripheral Situation was firstly put forward by German existentialist philosopher Karl Theodor Jaspers(1883-1969). It refers to the situation that "If someone encounters accidents, such as losing of relatives, breakdown of his or her family, incurable diseases, most dangerous situations, mental dissociation, crime and depravity, there will be breakages in their connections with other people, their own ego and even with God. When death bursts into one's life as his or her individual worlds collapse, they are likely to doubt themselves, life, experiences and their belief. Sometimes this kind of doubts and deny is strong enough to overrun his or her entire world."

The Book of Job of the Old Testament is an existentialist drama which embodies the peripheral situation theory. As one of the two masterpieces of the Old Testament, the Book of Job raised a thousand-years-long debate over Pious People Suffers. As God stands by and Satan commits crimes capriciously, job can do nothing but toss and turn. This depicted a peripheral situation, which serves as a moving and tragic background against which job’s exploring of his soul was revealed.
\end{abstract}

\section{Introduction}

Job’s suffers originate from a bet between God and Satan, namely Satan asserts that “ If put forth thine hand now, and touch all that he hath, this pious servant who is perfect and upright and fearing god while eschewing evil will curse thee to thy face”, (The Book of Job 1:1, 1:11 )and God allow Satan's test. At first, Satan bereaved all of Job's family property and all of his ten children, then he smote Job with sore boils from the sole of his foot unto his crown. Having stopped complaints from his wife, however, job came clean to three of his friends and told them all of his doubts, sorrows, anger and despair in their conversation. Job wailed and whined, all he want is finishing this painful life, "Oh that I might have my request; and that God would grant me the thing that I long for! Even that it would please God to destroy me; that he would let loose his hand, and cut me off!'(The Book of Job 6:8, 6:9). He didn't understand why the God he admired so high would let rounds of misfortune descend on him without any protection, and what he did wrong caused this kind of 
punishment? This is job’s peripheral situation.

The peripheral situation inherently manifests a kind of breakages, which exist in one's connections with other people and the rest of the world, and mainly characterized by sudden deaths. In his previous days, job enjoyed a normal and common life. With his sons and daughters, abundance in wealth, job led so pious, meaningful and substantial a life that he often offered up sacrifice unto the Lord. But this is just an Unreal Situation in Martin Heidegger's eyes (1889-1976). After his beloved children, family property and loyal servant were took away overnight, Job was pushed to the verge of peripheral situation. And for himself, an unbearably ulcer all over his body locked him in a ceaseless struggle with death. Because of death, this unreal situation stopped, therefore his connections with other people and the rest of the world were also cut off. As far as Jaspers concerned, a peripheral situation is like a wall, people as physical existences would definitely and completely fail after they hit the wall. Then, in the shock of the failure, the limits of a physical existence were demonstrated and the real living condition revealed.

"He teareth me in his wrath, who hateth me: he gnasheth upon me with his teeth; mine enemy sharpeneth his eyes upon me."( The Book of Job 16:9). This short verse mentioned two kinds of breakages: with other people and the rest of the world. God is the existent while we are merely the existence. Vladimir Solovyov (1853-1900) said: "God is the existent, namely he is the owner of beings or existences belong to him....Logically, existence can only be considered as the connection between the existent and his or her objective nature and contents. And existent in turn assures, regulates and unveils the nature and contents with different methods." In this connection, the breakage between existence and existent means the loss of nature, meanwhile, the breakages between existences are just some kinds of additional products of the former one. "The deviation of the relationship between man and God necessarily leads to the breakages between people.” To job’s shock, when he made complaints in front of his friends, their responses were much of criticizes. And this indicates Job's breakages with other people, which made job confused and desperate about the loss of man's nature.

And Job started his painful thinking. Lev Shestov (1866-1938) said that:” the moments of despair are the most solemn and grand time in life...... Also during the most difficult hours, our thoughts are most conflicted." As an upright and pious servant, Job was convinced of the almighty God and the fact that God rules the word, but he doubted that whether there is his position in that world and lost his nature and existence. He had no idea about the relationship between the existent and existences. He asked why he was once treated as a close friend of God but now be punished even if he hasn't done anything wrong? He raised a host of anxious and even impatient questions: "If I have done wrong, what have I done to you, O keeper of men? why have you made me a mark for your blows, so that I am a weariness to myself? And why dost thou not pardon my transgression, and take away mine iniquity?” (The Book of Job,7:20,7:21)

“As empirical appearance, people have to be rational existences”. From the rational angle, Job he who regarded himself as an upright man since he had made no crime, and this in turn made him can't understand why did he be caught up in the peripheral situation. Based on his conduct, Job pretty affirmed that his behavior is perfect. With a long history of legalism, Judaism attaches great importance to laws and principles, such as Ten Commandments, in an effort to regulate people to be upright and perfect. However, the peripheral situation toppled Job's understanding and destroyed his long-term illusion that he is so upright and perfect. Amid suffers, Job thought "what's meaning of being justified? Is being justified all about good behaviors? Is my moral quality strong enough to underpin the burden of being justified? If it could, why did I be reduced to this?”

As for this question, job gave a positive answer. His explanation came from his good 
behaviors---he is a mode of moral equality, he who is loyal in marriage, fair in treating people, warm-hearted to friends, non-greedy of money, determined in believe and not coveting other's land. He loudly defended himself: "Is there iniquity in my tongue? cannot my taste discern perverse things?”(The Book of Job, 6:30), answered his friends: “Teach me, and I will hold my tongue: and cause me to understand wherein I have erred. How forcible are right words! but what doth your arguing reprove?” (The Book of Job, 6:24, 6:25), and he even wanted to pled his innocence in front of God, " Oh that I knew where I might find him! that I might come even to his seat! I would order [my] cause before him, and fill my mouth with arguments" and " Thou knowest that I am not wicked" He pledged that: " My lips shall not speak wickedness, nor my tongue utter deceit." and “ My righteousness I hold fast, and will not let it go: my heart shall not reproach me so long as I live."

If behavior is deemed as the basis and fundamental of being righteous, job's despair and disappointment come very naturally. As a justified man, he deserve no suffer or punishment. But if we look at the reality, we can easily find that due to the lack of final value criteria, our moral quality changes in tandems with our standings. And it tends to be vague as it constantly changes. In this connection, people's behavior is too untenable to underpin the meaning of being justified. However, being justified here is much more than a distillation of Moralism, it's a brand new point of view, an eternal vision and an ultimate value measurement. It's ridiculous and pathetic to define God's eternal measurement with a set of moral criteria that is supported by reality of human's society! Sinclair Ferguson (1948-) said in his book Justification that: "Our biggest temp and mistake are trying to confuse moral character issues with other favor behaviors ". "The meaning of sin is mainly to show the breakage in man's connection to God". Job's pain came from his self-righteousness.

\section{Reconstructions of connections}

The narrative structure of The Book of Job is a U-structure, with the breakages of people and God's relationship as starting point and the reconstruction of the relationship as another point. This kind of reconstruction was built on the deadly wall in peripheral situation. In the pain of butting heads against the wall, people learn of their limits as existences and then get inspired to return to their nature and finally become a true man.

From the contents we know that Job wasn't punished for his committed crimes. His self-righteousness made him defend and explain for himself, and his understanding of God is revealed by this kind of self-righteousness. Job believed that God also regards man's moral as a benchmark, since he had done no evil things, he should be declared as justified. However, God's definition of Being Justified is inherently different from the one of people's code of ethics. Man's code of ethics is invariably tinged with the non-self-sufficiency that comes from people's nature, however, in God's eyes, being justified is a spirit of transcendental. Man's moral quality doesn't cover all corners of God's world, meanwhile God owns all of the infinites and finites, so Shestov said: "God's world is definitely much more abundant than ours". God's answer of Job's question "what is righteousness" is somehow hard to understand, but from his words, "I laid the foundations of the earth, brake up for the sea my decreed place, commanded the morning since thy days, walked in the secret places of the deep, found the way to the resting-place of the light and the store-house of the dark, divided a watercourse for the overflowing of waters and a way for the lightning of thunder" (The Book of Job), we know that what behind God's questions is the stress that "I am the lord of everything". Similarly, the reason why God mentioned the universe is that he want to tell the world that: " I created and is in charge of everything”. Everything in the world has a position. 
After Compared himself with earth, sea, light, thunder and wild beasts, Job learned of his own position in the world. As any other species in this world, we are nothing but God's creations. Is a creation able to conclude his lord? Is man's code of ethic broader than the scope of God's righteousness?

God's answer made Job "To realize his rational illusion and the deficiency of the meaning of morality, and he found that he couldn't answer the question that what is righteousness". After painful shouts and thinking, he was fully of man's insignificance and limits. He realized God's greatness and confessed in regrets: "Truly, I am of no value; what answer may I give to you? I will put my hand on my mouth." "I see that you are able to do everything, and to give effect to all your designs." "Word of you had come to my ears, but now my eye has seen you." When he knew God from ears, there is still a long distance between him and God, therefor, his understanding of a God is necessarily stuck in a shallow level. But when he could see God, a closer relationship between him and God was established and Job finally found his position in the universe. Because "we have to recognize that the most profound essence of human beings is rooted in the eternal world created by God, we have recognize that this world is not only a visible phenomenon, such as a string of appearances or facts, but also an eternal and special existence and an indispensable and necessary part of the absolute overall."

\section{Modern appearance of the peripheral situation from The Book of Job}

In the Old Testaments.The Book of Job , Job’s puzzles and thinking was deeply described, and meanwhile the breakages and reconstructions of his connections with God, other people were vividly represented. The core factor which led to job's change is belief. Committed to belief, job finally got out of the dilemma of self-righteousness. This kind of dilemma was once happened to Tolstoy (1828-1910), he who gave up his title and asset out of his sympathy of poverty-stricken people. With a hope to feed himself by his own hands rather than exploiting people, the great writer refused the lifestyle of nobility and began to engage in strenuous labor works. However, his puzzles didn't dissolve by his actions, to his disappointment it grew as the time goes by. Finally, the literary giant passed away in a rural railway station as he run away from home all by himself. With Tolstoy's respected yet pitiful experience, we know that the peripheral situation of Job is not an accident, it's inevitable throughout our search of God, truth and selves. Only after trying and failure can we finally obtain the essence and deepest meaning of life.

\section{Acknowledgement}

Funded Item: 2014 Special Fund for the Planning of Xi'an Social Sciences

(Item Number: 14XF20)

\section{References:}

[1] Liang Xudong. Confronted with Marginal Contextualization: A Study on Western Literary Classics[M]. Beijing, 2004:1.

[2] National Committee of Three-Self Patriotic Movement of the Protestant Churches in China. China Christian Council. Bible The Old Testament.

[3] [Russia] Viladmir Solovyov, Zhang Baichun translated. Lectures on Divine Humanity[M]. Beijing: Huaxia Publishing Home, 1999:79,79,113,124.

[4] Liu Xiaofeng. Saving and Unconstrained[M].Shanghai: Press of East China Normal University, 
2007:154,154,141.

[5] [Russia] Lev Shestov, Fang Shan translated. Apotheosis of Groundlessness[M].Xi' an: Shaanxi Normal UP, 2003:162.

[6] Sinclair Fugerson. The Justification. http://www.crca.com.cn/show.aspx?id=5209\&cid=89 